\title{
TUJUAN PENDIDIKAN NASIONAL DALAM PERSPEKTIF PANCASILA
}

\author{
Oleh: \\ Rukiyati (rukiyati@uny.ac.id) \\ Universitas Negeri Yogyakarta
}

\begin{abstract}
ABSTRAK
Tujuan pendidikan yang terdapat di dalam Undang-Undang Nomor 20 Tahun 2003 tentang Sistem Pendidikan Nasional adalah untuk mengembangkan kodrat manusia yang bersifat multidimensional dan holistik. Hubungan antar-komponen tujuan bersifat satu kesatuan integral dan ada hierarki nilai-nilai dalam pencapaian tujuan tersebut. Aspek-aspek kodrati manusia dilihat sebagai suatu potensi yang perlu dikembangkan agar manusia mencapai kualitas pribadi sebagai insan yang berakhlak mulia, baik ketika berhadapan dengan Sang Pencipta dalam terminologi iman dan takwa (ketuhanan) maupun ketika berhadapan dengan sesama makhluk dalam kehidupan dunia (kemanusiaan, persatuan, kerakyatan, dan keadilan sosial). Tujuan pendidikan sebenarnya merupakan nilai-nilai Pancasila dalam formulasi yang lain, karena sesungguhnya landasan filsafat pendidikan nasional Indonesia adalah Pancasila.
\end{abstract}

Kata kunci: tujuan pendidikan, undang-undang, manusia, nilai-nilai, Pancasila.

\begin{abstract}
ABTRACT
The educational objectives contained in Act Number 20 of 2003 concerning the National Education System in Indonesia are to develop multidimensional and holistic human nature. The relationship between the components of the goal as an integral whole and there is a hierarchy of values in the achievement of goals. The natural aspects of humanity are seen as a potential that needs to be developed so that humans reach personal qualities as human beings who have noble character, both when dealing with the Creator in terms of faith and piety (believe in one God) and when dealing with fellow creatures in world life (humanity, unity, democracy, and social justice). The purpose of education is actually the values of Pancasila in another formulation, because in fact the foundation of Indonesia's national education philosophy is Pancasila.
\end{abstract}

Key words: aim of education, laws, human being, values, Pancasila.

\section{PENDAHULUAN}

Tujuan pendidikan merupakan bagian yang tak-terpisahkan dari praktik pendidikan. Tujuan pendidikan berisi nilai-nilai yang hendak diwujudkan dalam proses atau kegiatan pendidikan. Tanpa nilai-nilai yang jelas, praktik pendidikan berjalan tanpa landasan yang kokoh. Jika yang demikian terjadi, itu berarti belum terjadi praktik pendidikan. Sebagaimana dinyatakan oleh Uyoh Sadulloh (2007:58) bahwa tujuan pendidikan merupakan gambaran dari falsafah atau pandangan hidup manusia, 
baik secara perseorangan maupun kelompok. Membicarakan tujuan pendidikan akan menyangkut sistem nilai dan norma-norma dalam suatu konteks kebudayaan, baik dalam mitos, kepercayaan, religi, filsafat, ideologi dan sebagainya. Oleh karena pendidikan merupakan suatu proses sengaja dari suatu generasi kepada anak didik sebagai generasi penerus yang lebih baik, maka tujuan pendidikan diarahkan oleh perseorangan atau kelompok suatu generasi pada cores value yang telah dipikirkan atau disepakati bersama.

Noeng Muhadjir (2003:1-2) mengatakan bahwa aktivitas pendidikan tidak dapat berlangsung bila tidak ada dua unsur, pertama, yang memberi (pendidik/guru) dan yang menerima (peserta didik), tetapi, kedua unsur tersebut belum memberi rona pendidikan sehingga disyaratkan unsur yang ketiga, yaitu tujuan baik dari yang memberi bagi perkembangan atau kepentingan yang menerima. Makna baik secara filosofis mencakup: etiket, conduct atau perilaku terpuji, virtues atau watak terpuji, practical values sampai living values. Agar anak pandai, agar orang menjadi ahli, agar orang bertambah cerdas, agar orang berkepribadian luhur, agar orang toleran, agar anak pandai membaca, dan banyak lagi contoh tujuan baik yang dapat menjadi unsur ketiga pendidikan. Dari contoh-contoh tersebut dapat dibedakan tiga tujuan baik, pertama: tujuan baik yang berfungsi sebagai alat atau instrumental values untuk mencapai tujuan lain. Kedua, tujuan yang berada dalam subjek itu sendiri, yaitu perkembangan dan pertumbuhan subjek itu sendiri, seperti mempunyai watak terpuji, Ketiga, tujuan yang merupakan sesuatu yang ideal, sesuatu yang berada di luar subjek, yang disebut practical values dan living values.

Dalam kerangka living values inilah negara sebagai organisasi masyarakat yang paling luas juga mempunyai tujuan pendidikan yang mencerminkan kehendak anggotaanggotanya melalui suatu mekanisme formal dalam bentuk perundangundangan. Setiap negara mempunyai tujuan pendidikan sendiri-sendiri tergantung ideologi negara dan kebijakan dasar pemerintahnya. Indonesia sejak berdiri tahun 1945 sampai saat ini telah memiliki perundang-undangan pendidikan dan upaya penyempurnaannya. UndangUndang Nomor 20 Tahun 2003 adalah 
undang-undang terbaru yang sekarang berlaku mengenai Sistem Pendidikan Nasional. Di dalamnya memuat sejumlah nilai-nilai yang menjadi tujuan pendidikan Indonesia.

Tulisan ini akan menganalisis tujuan pendidikan nasional dalam perspektif nilai-nilai Pancasila sebagaimana terdapat di dalam pasal 3 UU Nomor 20 Tahun 2003 dengan fokus pada: 1) Makna masing-masing nilai sebagai tujuan yang ingin dicapai; 2) Hubungan antar-komponen tujuan sebagai satu kesatuan integral; 3) Hierarki nilai-nilai dalam pencapaian tujuan; 4) Landasan filosofis tujuan pendidikan nasional.

\section{PEMBAHASAN}

1. Makna masing-masing nilai sebagai tujuan pendidikan

Pasal 3 Undang-Undang Sistem Pendidikan Nasional menyebutkan bahwa pendidikan nasional berfungsi mengembangkan kemampuan dan membentuk watak serta peradaban bangsa yang bermartabat dalam rangka mencerdaskan kehidupan bangsa, bertujuan untuk berkembangnya potensi peserta didik agar menjadi manusia yang beriman dan bertakwa kepada Tuhan
Yang Maha Esa, berakhlak mulia, sehat, berilmu, cakap, kreatif, mandiri dan menjadi warga negara yang demokratis serta bertanggung jawab.

Dari pernyataan tersebut dapat dijabarkan makna sebagai berikut.

a. Manusia beriman dan bertakwa kepada Tuhan Yang Maha Esa.

Pendidikan bertujuan mengembangkan potensi rohaniah manusia sebagai makhluk ciptaan Tuhan. Manusia beriman artinya orang yang percaya akan adanya Dzat yang mutlak (absolut) yang transenden, mengatasi dirinya dan segala sesuatu di alam ini, sesuatu yang menjadi penyebab adanya alam dan isinya, tetapi tidak disebabkan oleh yang lain (Causa Prima). Sedangkan manusia bertakwa adalah orang yang karena meyakini adanya Tuhan kemudian berusaha mengarahkan segala perasaan, pikiran dan tingkah lakunya berdasarkan perintah Tuhan. Secara sederhana orang bertakwa adalah orang yang berusaha menjalankan perintah Tuhan dan menjauhi segala laranganNya. Tentu saja, ajaran tentang perintah dan larangan ini sesuai dengan agama atau keyakinan yang dianut oleh masingmasing individu peserta didik. Intinya, 
orang bertakwa adalah orang yang hati-hati dalam hidupnya agar tetap berada di jalan Tuhan.

Tujuan ini diwujudkan dalam sistem persekolahan Indonesia dengan memberikan materi pelajaran Pendidikan Agama mulai dari jenjang sekolah dasar sampai perguruan tinggi. Harapannya, peserta didik mencapai derajat sebagai orang yang bertakwa.

b. Berakhlak mulia

Akhlak berasal dari bahasa Arab yang biasa diartikan tabiat, perangai, kebiasaan, bahkan agama (Shihab, 1996:253). Bentuk tunggal kata akhlak adalah khuluq yang berkaitan erat dengan kata: makhluq (ciptaan) dan Khaliq (Pencipta). M. Quraish Shihab (1996:261) mengatakan bahwa akhlak mencakup berbagai aspek, dimulai dari akhlak terhadap Allah hingga kepada sesama makhluk (manusia, binatang,tumbuh-tumbuhan dan benda-benda tak-bernyawa)

Istilah yang hampir sama adalah moral (jamak dari mos yang artinya adat istiadat). Manusia berakhlak mulia adalah manusia yang berperilaku baik, artinya perbuatannya mencerminkan nilai-nilai kemanusiaan yang luhur seperti jujur, menghormati orang lain (respect), mencintai sesama, bertanggung jawab (responsibility), dan adab kesopanan yang berlaku di masyarakatnya. Thomas Lickona (1991:53) mengatakan bahwa komponen-komponen karakter yang baik mencakup pengetahuan moral (moral knowing), perasaan moral (moral feeling) dan tindakan moral (moral action), sedangkan Ki Hadjar Dewantara (1977: 20) mengatakan bahwa pendidikan budi pekerti (pendidikan moral) sebagai bagian penting dari pendidikan secara keseluruhan bertujuan untuk menjadikan peserta didik dapat menguasai diri sehingga ia dapat melenyapkan atau mengalahkan tabiattabiat biologis yang tidak baik. Jika pendidikan budi pekerti dapat dilaksanakan dengan baik dan kokoh sehingga dapat mewujudkan kepribadian (persoonlijkheid) dan "karakter" (jiwa yang berazas hukum kebatinan), maka peserta didik akan senantiasa dapat mengalahkan nafsu dan tabiat-tabiatnya yang asli, yang biologis tidak baik.

Tugas pendidikan moral adalah membantu peserta didik supaya memiliki karakter atau akhlak atau 
budi pekerti yang baik, sekaligus dimilikinya dalam diri peserta didik, pengetahuan, perasaan, dan tindakan moral yang saling melengkapi satu sama lain, dalam suatu kesatuan organis harmonis dinamis. Sedangkan tujuan pendidikan moral adalah membantu peserta didk agar menjadi bijak atau pintar (smart) dan membantu mereka menjadi orang yang baik. Baik dalam artian ini adalah dimilikinya nilai-nilai yang dapat memperkokoh martabat manusia dan mengembangkan kebaikan individu dan masyarakat (Dwi Siswoyo, 2008). Untuk itu, diperlukan pengembangan moral peserta didik, yaitu proses pengembangan regulasi perilaku berdasarkan sistem norma yang diinternalisasi. Apa yang membantu fokus pada norma? Dalam aspek kognitif itu adalah pengetahuan tentang norma dan konsekuensi dari melanggar norma, dalam aspek emosional orientasi pada perasaan emosional tentang perilaku orang (Molchanov, 2013: 616)

Sebenarnya, orang yang beriman dan bertakwa sudah implisit di dalamnya akhlak mulia, tetapi untuk lebih memperjelas tujuan pendidikan nasional, maka istilah "berakhlak mulia" disebutkan juga. Kemungkinan ini adalah upaya untuk memberi ruang bagi pendidikan budi pekerti yang dahulu sempat menjadi polemik agar dihidupkan kembali.

c. Sehat

Manusia sehat adalah orang yang fisiknya kuat, segar dan dapat melakukan aktivitas tanpa hambatan. Orang yang sehat ditunjukkan dengan semangat hidup dalam beraktivitas. Dalam Kamus Besar Bahasa Indonesia dinyatakan bahwa sehat artinya antara lain adalah: 1) Baik seluruh badan serta bagian-bagiannya (bebas dari sakit); 2)Waras; 3)Yang mendatangkan kebaikan pada badan.

Ada ungkapan dalam bahasa Latin: mensana in corpore sano yang artinya adalah jiwa yang sehat dalam tubuh yang sehat. Maksudnya, jika jiwa seseorang sehat, maka tubuhnya akan sehat juga. Begitu juga sebaliknya. Walaupun pernyataan ini tidak mutlak berlaku umum, tetapi secara mayoritas dapat dikatakan bahwa kesehatan merupakan syarat penting bagi anak didik untuk dapat belajar, bekerja dan bermain. Artinya, dengan bekal kesehatan, seseorang 
dapat berkontribusi dalam menciptakan kehidupan dunia yang lebih baik.

d. Berilmu

Pendidikan bertujuan menjadikan peserta didik berilmu. Artinya berbagai disiplin ilmu dapat dikuasai oleh peserta didik. Ilmu adalah kumpulan pengetahuan dengan objek tertentu, diperoleh dengan menggunakan metode yang tepat, disusun secara sistematis untuk memperoleh kebenaran yang berlaku umum/universal (Rukiyati, dkk.: 7). Dengan ilmu yang bermanfaat, manusia dapat mengelola alam ciptaan Tuhan secara harmonis, seimbang sehingga tidak mendatangkan kerusakan bagi dirinya dan dunia ini. Bila hidup seseorang dbekali ilmu, maka ia akan menjadi semakin mudah, nyaman dan lancar dalam menjalani hidup, karena ia akan lebih mudah mendapatkan solusi dari setiap problem yang dihadapi dibandingkan dengan orang yang tidak berilmu. Dengan kata lain, ilmu menjadi bekal hidup bagi peserta didik agar tidak mudah dikecoh dan jauh dari keterjajahan. Dengan ilmu manusia menjadi lebih produktif dan mempunyai nilai tambah dalam hidupnya.

e. Cakap

Cakap artinya hampir sama dengan trampil atau mempunyai kompetensi dalam melakukan suatu tugas atau keahlian yang dapat ditunjukkan hasilnya. Cakap berhitung artinya dapat mengerjakan hal-hal yang berkaitan dengan operasi hitung (kali, bagi, tambah dan kurang, dsb.) Cakap mengatasi masalah artinya dapat mengambil keputusan dengan tepat. Cakap bertindak secara proporsional, maksudnya bertindak yang seharusnya. Cakap berkomunikasi sama artinya dengan dapat menyampaikan pesan dengan baik, dapat menghargai dan meyakinkan orang lain yang diajak berbicara.

Terkait dengan kecakapan, peserta didik dipersiapkan menjadi sosok anggota masyarakat masa depan yang adaptif terhadap perubahan dan berkecakapan hidup. Peserta didik diarahkan memiliki kecakapan tertentu yang memungkinkannya kelak mampu melestarikan dan mengembangkan peradaban dan nilai-nilai luhur bangsa. Terlebih lagi saat ini yang disebut era 
Revolusi Industri 4.0, yakni era yang menekankan pada pola digital economy, artificial intelligence, big data, robotic, dan sebagainya atau dikenal dengan fenomena disruptive innovation. Era Revolusi Industri 4.0 mempunyai logika baru yang sama sekali berbeda, dan dapat melenyapkan yang lama. Ada tantangan-tantangan berat yang dihadapi di era ini terlebih untuk generasi muda. Seberat apapun tantangan itu, belajar adalah kunci menghadapinya. Ada lima kecakapan yang permintaannya akan paling tinggi dalam beberapa sektor industri sampai sekarang (tahun 2020), yang sebelumnya sektor tersebut tidak membutuhkannya. Kelima keterampilan adalah: 1) kemampuan untuk memecahkan masalah yang asing dan belum diketahui solusinya di dalam dunia nyata (Complex Problem Solving); 2) kemampuan untuk melakukan koordinasi, negosiasi, persuasi, mentoring, kepekaan dalam memberikan bantuan hingga kecerdasan emosional (Social Skills); 3) Kemampuan terdiri dari: kecakapan mendengarkan secara aktif, berpikir logis, memantau diri sendiri dan orang lain (Process Skills); 4) Kemampuan untuk dapat melakukan penilaian dengan pertimbangan cost-benefit serta kemampuan untuk mengetahui bagaimana sebuah sistem dibuat dan dijalankan (Systems Skills); 5) Kecakapan yang terdiri dari antara lain: fleksibilitas kognitif, penalaran logis, kepekaan terhadap masalah, visualisasi matematik (Cognitive Abilities) (Paristiyanti, dkk. 2016: 5). Tanpa banyak memiliki kecakapan hidup, manusia di era global menjadi tertinggal, bahkan tidak sekedar tertinggal, malah menjadi korban karena terlindas gerak zaman.

f. Kreatif

Daya jangkau pikir manusia tidak terbatas. Banyak hal tak-terduga dapat muncul dari pemikiran manusia yang kreatif. Pendidikan bertujuan menjadikan peserta didik menjadi insan yang kreatif, artinya manusia yang dapat menciptakan hal-hal yang baru, cara-cara baru, pemikiran baru atau ide-ide segar. Disadari sepenuhnya bahwa dimensi kreatif dapat ke arah positif maupun negatif. Kreatif yang dimaksudkan di sini tentu saja ke arah yang positif (berdimensi nilai). 
Pada dasarnya setiap manusia itu kreatif, tetapi sering kita tidak menyadarinya atau tidak memanfaatkan potensi kreatif dalam dirinya. Kreativitas manusia dapat dibangun terus-menerus, baik secara pribadi maupun kelompok. Kreativitas dapat dilakukan dengan langkah $3 \mathrm{~N}$ : Niteni (mengamati), Niroke (menirukan), Nambahi (menambahkan yang baru). Orang kreatif selalu bertanya: Apakah sesuatu dapat dikerjakan dengan lebih baik? Apakah sesuatu dapat dikerjakan berbeda dengan yang lain?

Jalan buntu tidak pernah ada pada diri orang kreatif. Hulu kreativitas adalah optimisme dan muaranya adalah inovasi. Orang kreatif selalu mempunyai solusi atas problematika hidupnya dan ada hal-hal baru sebagai penyempurnaan karyanya. Oleh karena itu, selayaknya bila salah satu unsur tujuan pendidikan nasional adalah menjadikan peserta didik kreatif.

g. Mandiri

Secara sederhana mandiri diartikan dengan tidak bergantung pada pihak manapun juga. Mandiri artinya memiliki otonomi atas dirinya, baik otonomi dalam berpikir maupun berbuat. Orang yang mandiri Ingin melakukan sesuatu sendiri dan tidak menyukai campur tangan orang lain. Orang dapat mandiri kalau ia telah dilatih dan dibiasakan untuk melakukan sesuatu hal terutama dengan upayanya sendiri. Juga, orang dapat dikatakan mandiri kalau ia telah dapat hidup atas usahanya sendiri. Berkaitan dengan itu, kemandirian berdimensi dua, yaitu orang yang tidak banyak bergantung pada orang lain dan dapat menghidupi dirinya sendiri. Kemandirian mengandung makna juga bahwa seseorang bertanggung jawab atas pilihan-pilihan hidupnya.

Kemandirian mengantarkan peserta didik menjadi sosok pribadi yang eksis, sedangkan ketidakmandirian berdampak luas. Orang yang tidak mandiri selalu berada dalam ketergantungan, kondisi tidak matang dan tertinggal. Sosok peserta didik yang tidak mandiri menghambat perkembangan diri, mengacaukan kepentingan bersama yang ujungujungnya merugikan diri sendiri dan masyarakat luas.

h. Warga negara yang demokratis dan bertanggung jawab 
Pendidikan nasional berada dalam lingkup negara. Warga negara yang demokratis merupakan salah satu tujuan pendidikan, karena negara Indonesia adalah negara demokrasi. Saat ini Indonesia berada dalam transisi demokrasi. Untuk mencapai demokrasi yang matang, warga negara harus dididik untuk menjadi orang yang demokratis. Orang yang demokratis menghargai adanya perbedaan pendapat dan berniat baik untuk membangun konsensus.

Warga negara yang bertanggung jawab merupakan tujuan pendidikan yang berhubungan erat dengan warga negara demokratis. Seseorang yang memiliki kebebasan bertindak dalam alam demokrasi dituntut pula untuk bertanggung jawab atas segala perbuatannya. Kebebasan berpendapat, kebebasan berusaha, kebebasan berpikir dalam alam demokrasi tidak bersifat mutlak, tetapi selalu diikuti oleh pertanggungjawaban atas pilihanpilihannya.

Robert A. Dahl (Sunarso, 2010: 3) mengajukan lima kriteria bagi demokrasi sebagai sebuah ide politik, yaitu : (1) persamaan hak pilih dalam menentukan keputusan kolektif yang mengikat; (2) partisipasi efektif, yaitu kesempatan yang sama bagi semua warga negara dalam proses pembuatan keputusan secara kolektif; pembeberan kebenaran, yaitu adanya peluang yang sama bagi setiap orang untuk memberikan penilaian terhadap jalannya proses politik dan pemerintahan secara logis; (4) kontrol terakhir terhadap agenda, yaitu adanya kekuasaan eksklusif bagi masyarakat untuk menentukan agenda mana yang harus dan tidak harus diputuskan melalui proses pemerintahan, termasuk mendelegasikan kekuasaan itu pada orang lain atau lembaga yang mewakili masyarakat; dan (5) pencakupan, yaitu terliputnya masyarakat mencakup semua orang dewasa dalam kaitannya dengan hukum. Paparan Dahl tersebut dapat dilihat relevansinya dengan pemikiran para the founding fathers yang telah maju ketika memilih demokrasi sebagai sistem pemerintahan Indonesia.

Dari berbagai aspek tujuan pendidikan Indonesia yang tercantum di dalam Undang-Undang Nomor 20 Tahun 2003 menunjukkan bahwa tujuan mengarah pada pencapaian diri ideal peserta didik sebagai manusia 
yang multidimensional. Perilaku baik berkaitan dengan relasi manusia dan Tuhannya, manusia dengan diri sendiri dan sesamanya, serta manusia dan negaranya.

2. Hubungan Antar-komponen Tujuan Pendidikan

Berdasarkan uraian masingmasing komponen tujuan dapat direfleksikan suatu tujuan umum yang melandasinya. Dilihat dari komponen tujuan, tujuan pendidikan nasional Indonesia bertitik tolak dari pandangan bahwa manusia pada hakikatnya adalah makhluk monopluralis. Artinya, manusia itu pada hakikatnya adalah satu pribadi tetapi berdimensi banyak, yaitu dilihat dari dimensi susunan kodrat, sifat kodrat dan kedudukan kodrat (Notonagoro, 1987:10). Masing-masing aspek tidak dapat dipisahkan karena membentuk diri pribadi manusia tersebut. Dilihat dari aspek susunan kodrat, manusia adalah makhluk berjiwa-raga. Oleh karena itu pendidikan diarahkan agar mempunyai tujuan untuk memuliakan jiwa dan raga. Memuliakan jiwa dilakukan dengan olah jiwa berupa pencarian nilai-nilai kebenaran (ilmu pengetahuan), kebaikan (moral) dan keindahan (estetik). Sedangkan pemuliaan raga dilakukan dengan memelihara badan agar tetap sehat dan segar. Dilihat dari sifat kodratnya manusia adalah makhluk individual sekaligus makhluk sosial. Untuk mewujudkan dimensi individu, tujuan pendidikan menekankan pentingnya menghargai kecakapan dan kreativitas pribadi dalam diri seorang peserta didik, agar ia dapat menjadi individu yang mempunyai kepribadian sendiri, persona yang unik dengan potensipotensi yang tidak sama dengan individu yang lainnya. Akan tetapi, selain sebagai makhluk individual, manusia sekaligus juga adalah makhluk sosial, maka dalam tujuan pendidikan diarahkan agar ia menjadi orang yang dapat hidup dan berperan aktif di masyarakat dengan menunjukkan dirinya sebagai partisipan aktif dalam kegiatan bersama. Oleh karena masyarakat Indonesia mengidealkan nilai-nilai demokrasi, maka diharapkan pula setiap peserta didik sebagai individu turut mewujudkan nilai-nilai demokrasi ini dan bertanggung jawab terhadap berbagai persoalan sosial secara bersama-sama, terlebih bila 
dalam lingkup negara yang kedudukan individu ini sebagai warga negaranya.

Dilihat dari aspek kedudukan kodratnya, manusia adalah makhluk otonom, mandiri dan juga sebagai makhluk Tuhan. Tujuan pendidikan diarahkan agar peserta didik memiliki kemandirian, artinya sekaligus ia diminta pertanggungjawaban atas segala putusan dan tindakannya. Walaupun demikian, kemandirian manusia tetap terbatas, artinya ia tetap harus mengakui bahwa ada hal-hal yang secara kodrati telah ditetapkan oleh Sang Khalik, karena manusia adalah makhlukNya. Dengan demikian pendidikan perlu mengarahkan peserta didik agar menyadari bahwa dirinya adalah makhluk yang bebas, tetapi terbatas. Keterbatasan ini menandakan kerendahan hati bahwa dirinya adalah makhluk Tuhan yang serba terbatas. Tujuan pendidikan berupa iman dan taqwa serta akhlak mulia terutama dilandasi suatu pemikiran bahwa kedudukan manusia sebagai makhluk Tuhan yang selalu patuh dan tunduk pada keputusan Tuhan.

Dari uraian di atas dapat disimpulkan bahwa tujuan pendidikan nasional sebagaimana terdapat di dalam UU No. 20 tahun 2003 dilandasi oleh filsafat manusia yang bersifat monopluralistik.

3. Hierarkhi Nilai-nilai dalam Pencapaian Tujuan

Dilihat dari uraian komponen tujuan, tampak sekilas ada hierarkhi yaitu beriman dan takwa serta berakhlak mulia didahulukan urutannya, baru diikuti urutan tujuan yang lain. Dengan kata lain, tujuan pendidikan nasional menekankan nilai-nilai perenial (abadi) sebagai yang pertama disebutkan. Oleh karena akhlak mulia mencakup seluruh aspek kehidupan, maka tujuan selanjutnya sebenarnya dipayungi oleh tujuan akhlak mulia tersebut. Dengan demikian dapat dikatakan bahwa "core"nya tujuan pendidikan nasional adalah akhlak mulia ini. Dengan akhlak mulia mengandung dimensi vertikal (iman dan takwa kepada Tuhan Yang Maha Esa) dan dimensi horizontal (berilmu, sehat, cakap, mandiri untuk dapat berkarya dan menjaga keharmonisan dunia).

\section{Landasan Filosofis Tujuan Pendidikan Nasional}


Ornstein \& Levine (2008; 394) mengatakan tujuan pendidikan nasional merupakan formulasi tujuan yang dirumuskan oleh suatu komisi khusus yang sangat bergengsi yang ditunjuk untuk itu, misalnya tujuan pendidikan nasional di Amerika Serikat berdasarkan The National Education Goals Panel Report (1998): “All children in America will start school ready to learn”. Walaupun tujuan tersebut sangat baik, masih tidak jelas bagaimana sekolahsekolah akan mencapainya. Tujuan nasional hanyalah pedoman umum untuk diikuti. Tujuan pendidikan yang masih bersifat umum tersebut adalah bagian penting dari pendidikan, walaupun tidak mungkin dapat langsung diamati atau dievaluasi karena masih berupa nilainilai umum.

Sebagaimana telah diketahui bersama bahwa pendidikan nasional Indonesia berdasarkan pada falsafah bangsa yaitu Pancasila. Tujuan pendidikan nasional sudah tentu diarahkan untuk mencapai nilai-nilai Pancasila. Hal ini terlihat dari masingmasing komponen yang kalau dianalisis akan memperlihatkan nilai-nilai Pancasila. Peserta didik yang sesuai dengan nilai-nilai Pancasila artinya ia adalah insan yang religius, humanis, nasionalis (cinta tanah air dan bangsa), demokratis dan adil-sejahtera. Idealitas ini ada kesejalanan dengan nilai-nilai yang menjadi tujuan pendidikan nasional, yaitu:

Ketuhanan = beriman dan bertakwa

Kemanusiaan $=$ akhlak mulia

Persatuan = bertanggung jawab

Kerakyatan $=$ demokratis

Keadilan sosial $=$ berilmu, cakap, kreatif, mandiri.

Titik tolak dalam Pancasila adalah manusia (sila II), demikian pula sebagai telah dipaparkan di atas bahwa core tujuan pendidikan adalah akhlak mulia. Jadi, tampak ada kesesuaian, bahwa tujuan pendidikan sejatinya bertitik tolak dari kodrat manusia dan bermuara pada perilaku yang diwujudkan dalam rumusan akhlak mulia.

Dalam perspektif pendidikan moral, tujuan akhlak mulia dalam pendidikan sarat dengan nilai-nilai moral yang ingin diwujudkan untuk meningkatkan martabat manusia. Akhirakhir ini di Indonesia lebih mengedepankan istilah pendidikan karakter daripada pendidikan moral. Sebenarnya, Althof \& Berkowitz (2006) 
mengatakan pendidikan moral, lebih merupakan domain moral daripada pendidikan karakter. Pendidikan moral berfokus pada pengembangan penalaran keadilan, menggabungkan moralitas relasional, dan penalaran tentang kepedulian terhadap sesama. Pendidikan karakter, karena membutuhkan pendekatan yang sangat luas, sering mengaburkan batas antara konsep moral dan konsep non-moral lainnya, tetapi terkait. Berkowitz (Althof \& Berkowitz, 2006) berusaha untuk menggambarkan yang terakhir sebagai 'karakteristik dasar', yang tidak langsung menunjukkan ciri bermoral (misalnya: ketekunan, kesetiaan, keberanian), tetapi berfungsi untuk mendukung agensi moral. Karakteristik dasar ini memperoleh status moral mereka dari tujuan moral atau tidak bermoral yang mereka terapkan. Kesetiaan dapat menjadi bernilai moral jika digunakan sebagai nilai bagi seseorang untuk melayani yang baik. Sebaliknya, kesetiaan menjadi tidak bermoral jika dilakukan untuk melayani tujuan yang jahat. Dalam konteks tujuan pendidikan di Indonesia tampak bahwa tujuan moral mendapatkan urutan yang lebih awal sehingga dapat dimaknai lebih dipentingkan, dibandingkan dengan tujuan untuk pengembangan intelektual dan keterampilan.

\section{PENUTUP}

Tujuan pendidikan yang terdapat di dalam Undang-Undang Nomor 20 Tahun 2003 bersifat holistik dan berusaha untuk mengembangkan kodrat manusia yang bersifat multidimensional. Jadi, tujuan baik yang ingin dicapai terlihat sangat banyak. Aspek-aspek kodrati manusia dilihat sebagai suatu potensi yang perlu dikembangkan agar manusia mencapai kualitas pribadi sebagai insan yang berakhlak mulia, baik ketika berhadapan dengan Sang Pencipta dalam terminologi iman dan takwa, maupun ketika berhadapan dengan sesama makhluk dalam kehidupan dunia. Tujuan pendidikan nasional bersifat hierarkis, yaitu mengedepankan iman dan takwa serta akhlak mulia sebagai hal yang melandasi tujuan yang lain. Tujuan pendidikan sebenarnya merupakan nilai-nilai Pancasila dalam formulasi yang lain. Hal ini memang sudah seharusnya demikian, karena pendidikan nasional Indonesia berdasarkan Pancasila. 


\section{DAFTAR PUSTAKA}

Althof, Wolfgang \& Marvin W. Berkowitz, 2006. "Moral education and character education: their relationship and roles in citizenship education". Journal of Moral Education. 35. 4.495-518. Published by Routledge.

Dewantara, Ki Hadjar. 1977. Pendidikan. Yogyakarta: Majelis Luhur Taman Siswa

Lickona, Thomas. 1991. Educating for Character. New York - Toronto - London - Sidney - Auckland: Bantam Books.

Molchanov, Sergey V. 2013. "The Moral Development in Childhood". Procedia - Social and Behavioral Sciences 86 ( 2013 ) 615 - 620. Published by Elsevier Ltd.

Muhadjir, Noeng. 2003. Ilmu Pendidikan dan Perubahan Sosial - Teori Pendidikan Pelaku Sosial Kreatif. Yogyakarta: Rake Sarasin.

Notonagoro. 1987. Pancasila secara Ilmiah Populer. Jakarta: Pantjuran Tujuh.
Ornstein, C. Allan \& Daniel U. Levine. 2008. Foundations of Education. Boston - New York: Houghton Mifflin Company.

Paristiyanti, dkk. 2016. Pendidikan Pancasila. Jakarta: Direktorat Jenderal Pembelajaran dan Kemahasiswaan Kementerian Riset, Teknologi, dan Pendidikan Tinggi Republik Indonesia.

Rukiyati, dkk. 2018. Pancasila. Yogyakarta: UNY Press.

Shihab, M. Quraish. 1996. Wawasan AlQuran. Bandung: Mizan.

Sunarso. 2010. "Demokrasi di Indonesia (Konsep, Prospek, dan Implementasinya)". Jurnal Humanika. Vol. 10. 1.

Uyoh Sadulloh. 2007. Pengantar Filsafat Pendidikan. Bandung: Alfabeta.

Undang-Undang Nomor 20 tahun 2003 tentang Sistem Pendidikan Nasional. 